\title{
CIDADE, TERRITÓRIO E REQUALIFICAÇÃO URBANA: programa Macambira-Anicuns na metrópole goianiense
}

\author{
Prof. Dr. Aristides Moysés \\ Mestrado em Desenvolvimento e Planejamento Territorial da Universidade Católica de Goiás \\ Av. Universitária 1.440 - Setor Universitário - CEP 74605-010 - Goiânia - GO - Brasil \\ Tel.: (55 62) 8467-6660 - arymoyses@uol.com.br \\ Sandra Sarno Rodrigues dos Santos \\ sandra@goiania.go.gov.br
}

\begin{abstract}
RESUMO
O Programa Macambira Anicuns foi idealizado originalmente em 2003 como um programa de intervenção no sistema viário da cidade de Goiânia. Por injunção do Banco Interamericano de Desenvolvimento (BID), o escopo do programa foi modificado. Os recursos necessários viriam de uma parceria entre a Prefeitura de Goiânia e o BID, e o custo total da obra está estimado em US\$ 94,5 milhões, sendo 60\% financiados pelo BID e 40\% pela Prefeitura de Goiânia. O mérito deste projeto, ainda não implantado, está na ruptura de uma prática histórica de intervenção urbanística que considerava apenas o transporte individual, substituindo-a por uma concepção holística, qual seja a de repensar o espaço urbano da região, qualificando-a sob a ótica ambiental e urbanística por meio de ações nas áreas de meio ambiente, habitação, equipamentos urbanos e sistema viário.
\end{abstract}

Palavras-chave: ordenamento urbano, recuperação ambiental, núcleos habitacionais, cursos d'água, requalificação urbana.

\begin{abstract}
In the beginning, the Macambira-Anicuns program was to be an intervention program in the road system of Goiânia city. The draft of the program was altered by influence of the interamerican bank of development (BID). The budget of the U\$S 94.5 million program, not yet accomplished, was supposed to be financed by the BID (60\%) and the municipality of Goiânia (40\%). The merit of this project is a rupture with the historical practice of urban intervention. Meanwhile, the individual transport was the center of these interventions, in future this project would implement a holistic concept of urban transport system. This would lead to re-think the urban space for that region, promoting a qualification from the environmental and urbanizing point of view, acting in questions of environment, dwelling, urban equipments and road system.
\end{abstract}

Key words: municipal statutes, ambient regeneration, dwelling-centers, watercourses, urban requalification

\section{RESUMEN}

El programa Macambira-Anicuns fue originalmente idealizado en 2003 como un programa de intervención en el sistema vial de la ciudad de Goiânia. Sin embargo, por determinación del Banco Interamericano de Desarrollo (BID), el objetivo inicial del programa fue modificado. Los recursos necesarios vendrán de un acuerdo cooperativo entre el ayuntamiento de Goiânia y el BID. El costo total de la obra está estimado en US\$ 94,5 millones, $60 \%$ de esos recursos serán financiados por el BID y 40\% por el ayuntamiento de Goiânia. El mérito de este proyecto (aún no implantado) está en la ruptura de una práctica histórica de intervención urbanística que consideraba únicamente el transporte individual y, en sustituir las prácticas antiguas por una concepción holística, cuyo objetivo es repensar el espacio urbano de la región, clasificándolo desde la óptica ambiental y urbanística, así como en actuar en las áreas del medio ambiente, vivienda, equipos urbanos y sistema vial.

Palabras-clave: organización urbana, recuperación ambiental, núcleos de viviendas, trayectorias del agua, recualificación urbana.

\section{INTRODUÇÃO}

Goiânia desenvolveu-se sob a égide do planejamento urbano e, em diversas fases, o seu crescimento esteve orientado por planos diretores. Alguns desses planos transformaram-se em Leis Complementares; outros, não foram além de meras cartas de intenção. Mesmo assim, a cidade não ficou imune à sanha do capital imobiliário e, tampouco, ao avanço desordenado da ocupação populacional em áreas inóspitas e distantes da malha urbana consolidada. Em uma cidade que ostenta o planejamento como símbolo de modernidade, é contraditório o avanço da ocupação em matas 
ciliares e várzeas junto aos cursos d'água. Compreende-se, pois, que as mazelas urbanas decorrem da lógica capitalista que orientou a sua construção, na perspectiva daquilo que se denominou de "marcha para o oeste", projeto dirigido pelo governo de Getúlio Vargas para ocupar e desenvolver o interior do Brasil.

Esta situação agrava-se, na medida em que a queda do poder aquisitivo da população, o desemprego e o êxodo rural acabam por provocar concentrações de população de baixa renda nas áreas que mais deveriam receber atenção no que se refere à preservação ambiental, ou seja, os fundos de vale. Estas concentrações populacionais que se localizam nas margens dos cursos d'água, na forma de favelas ou invasões, agravam mais ainda a situação de degradação, haja vista o acúmulo de lixo e entulhos nos cursos d'água, além do despejo de esgoto sanitário que agrega problemas sanitários à já difícil situação de drenagem.

A bacia do ribeirão Anicuns é a principal do Município. Seu corpo d'água é receptor das bacias dos córregos Macambira, Cascavel e Botafogo, drenando toda a área central de Goiânia e parte das regiões oeste, sul e leste, envolvendo uma cobertura populacional de cerca de $70 \%$ da população goianiense, segundo dados do IBGE, Censo 2000, regionalizados pela Secretaria Municipal de Planejamento. $\mathrm{O}$ avanço da ocupação de suas margens por residências, comércios e indústrias é intenso, inclusive em áreas de risco como as planícies de inundação. Esta situação, somada às condições sanitárias dos cursos d'água, cria uma condição imprópria e de risco à saúde pública e à segurança.

O processo de degradação dos vales do córrego Macambira e do ribeirão Anicuns tende a se intensificar, caso não sejam tomadas medidas para sua proteção e recuperação. Sem uma política habitacional séria e voltada para as populações com menor poder aquisitivo, a tendência é aumentar a ocupação clandestina dos fundos de vale, o que dificultará no futuro a sua reurbanização.

Neste sentido, a proposta do Programa Macambira-Anicuns, projeto executivo desenvolvido na gestão do governo municipal do período 2001-2004, pretende aliar a questão ambiental à urbanística, recuperando uma área urbana significativa dentro da cidade e transformando locais, hoje insalubres e de risco para a comunidade vizinha, em espaços organizados com habitações e equipamentos sociais.

Este programa tem como mérito romper com uma tradição de ocupação dos fundos de vale para atender ao sistema viário, em detrimento de propostas que consideravam a sua preservação para se tornarem espaços de lazer e de encontro. Trata-se, portanto, de um programa que pretende se contrapor às práticas passadas materializadas nas obras de canalização do córrego Botafogo, já concluídas, e nas do córrego Cascavel, em curso.

A estratégia de enfrentamento da degradação ambiental nas bacias do córrego Macambira e do ribeirão Anicuns ocorrerá em várias frentes, visando à recuperação de uma extensa área próxima ao centro da cidade. O conjunto de ações previstas implicará um processo de ordenamento urbanístico, de recuperação ambiental e de promoção da saúde pública, com impactos holísticos de grande relevância que beneficiarão um contingente populacional de aproximadamente 300 mil moradores. Neste sentido, cabe destacar quatro ações de caráter socioambiental: recuperação das faixas de proteção ambiental contíguas ao córrego Macambira e ao ribeirão Anicuns; criação de Unidades de Conservação Ambiental; implantação de núcleos habitacionais para o assentamento de famílias e implantação de melhorias em bairros situados nas áreas de influência direta e indireta do programa.

\section{ENQUADRAMENTO TEÓRICO DA QUESTÃO}

Está ficando desgastada a idéia de que Goiânia é uma cidade planejada. Planejamento é uma ferramenta técnica, científica e política muito séria que está sendo banalizada por intervenções exógenas. Intervenções exógenas, para efeito deste artigo, são as interferências de atores econômicos, sobretudo aqueles ligados diretamente ao mercado imobiliário (imobiliárias em geral, incorporadoras 
e construtoras). Como exemplo, vale lembrar os frequentes desrespeitos às legislações urbanas, para atender a execução de projetos que ficam paralisados em decorrência de restrições contidas na legislação urbana.

Esta prática é recorrente na história urbana de Goiânia, sendo praticada não só pelo capital imobiliário, mas também pelo poder público, quando este deseja implantar projetos de caráter populista e se defronta com restrições legais. Esta prática foi muito forte na década de 1980, quando a gestão municipal era submissa à gestão estadual, muito embora existissem prefeitos legitimamente eleitos pela população.

Inúmeros estudos já deram conta desta realidade. No caso da metrópole goianiense, existem vários estudos que vêm desvendando as contradições do processo de planejamento de Goiânia (MOYSES, 2004; MORAES, 1997, MORAES, 2003, BERNARDES, 1998). Esta cidade que virou metrópole e, em pouco tempo, assumiu o papel de centro regional, nasceu planejada e foi (des) planejada no percurso de sua emancipação urbanística a partir dos anos 1950.

Goiânia foi plantada no centro geográfico do país no início dos anos 30 e, desde a sua construção, foi marcada pela elaboração de vários planos de intervenção urbanística, na perspectiva de manter o sonho original do planejador e assegurar o crescimento ordenado da cidade (GODOY, 1942; SAIA, 1960/1964; WILHEIM, Jorge, 1969; LERNER, 1975, PDIG/2000). Vale dizer que os planos urbanísticos assumem a função de demarcadores do espaço urbano, na medida em que possibilitam contar o tempo da cidade, que se expressa no seu desenho urbano, e de que forma a dinâmica social rebate no espaço urbano. Neste sentido, a periodização ou divisão em ciclos é uma forma de se recortar no tempo os vários momentos da dinâmica de um fenômeno qualquer.

No caso de Goiânia, duas periodizações são muito utilizadas pelos estudiosos, a fim de se entender o processo de estruturação de sua malha urbana. Autoras como Narcisa CORDEIRO \& Normalice QUEIROZ (1990:7), por exemplo, identificam cinco grandes ciclos. Sérgio de MORAES (1991:32-33), por sua vez, identifica quatro fases na formação do espaço urbano de Goiânia. Estas leituras da construção do seu espaço urbano consideram, sobretudo, a dimensão física da cidade. Existe outro olhar acerca deste mesmo processo, MOYSÉS (2001 e 2004), denominado de movimentos de urbanização. Essa periodização leva em consideração não apenas os planos urbanísticos, mas também os aspectos sociais, políticos e econômicos de cada período. Isso permite lançar um olhar mais crítico sobre o processo de estruturação urbana de Goiânia, não apenas sob a ótica do desenho urbano, que na sua forma assume uma dimensão estática, mas também sob o ponto de vista da inclusão do homem no processo de construção da cidade.

Em resumo, os três movimentos de urbanização acima referidos, segundo MOYSÉS, 2004:124128, demarcam os seguintes tempos:

a) de 1933 a 1950: a cidade dos sonhos nasce de uma idéia. Nesse período a discussão estará centrada no processo de construção da cidade, tendo como base cartográfica o plano original elaborado por Atílio Corrêa Lima, alterado e ampliado por Armando Augusto de Godóy, contratado pela firma Coimbra Bueno. Tambem serão enfocados os recortes políticos do período, ou seja, a passagem do Estado Novo, com suas concepções intervencionistas, para um Estado com idéias liberais. Nesse período, apesar das contingências nacionais, predominam as teses intervencionistas. É a época da elaboração e implantação do plano original e do planejamento urbano, da consolidação de um projeto atrevido demais para ser desenvolvido no "cerrado", distante, desconhecido e esquecido pelo litoral, de onde emanava o poder central.

b) de 1951 a 1979: do sonho ao pesadelo. Nesse período consolida-se definitivamente um novo processo de "urbanização" de Goiânia. Os fluxos migratórios intensificam-se até os anos 1960; paralelamente, abandona-se o plano original e, com ele, o planejamento, assim como o projeto atrevido do período anterior. Enquanto no período anterior o Estado estivera presente na construção de uma cidade moderna e voltada para o homem, neste o Estado privatiza a construção da 
cidade, relegando-a à própria sorte. Constrói-se uma nova cidade, que se agiganta e se sobrepõe à que existia. Esta "nova cidade", diga-se, emerge sem que o planejamento exerça qualquer forma de controle. Entendo que a cidade de hoje nasceu em 1950, quando se desestrutura o seu espaço urbano. Em 1979, quando a população pobre, os chamados sem-teto, organiza-se e planeja a "invasão dos espaços vazios" reservados pela especulação, um "momento novo" inicia-se na região Noroeste da cidade, tendo como atores a população pobre, sem moradia e organizada. ${ }^{1}$

c) de 1980 a 1992: da fazenda Caveirinha à fazenda São Domingos. O movimento das invasões constitui um momento importante do processo urbano em Goiânia. O "atrevimento" da população marginalizada (julho de 1979) enseja um novo processo. Desta vez, o Estado atua às avessas do plano original. Se no período de 33-50 o Estado compra um espaço e nele planeja a construção de uma cidade, urbaniza-o e transforma-o num lugar digno de se viver, agora o Estado faz "quase" a mesma coisa, mas às avessas. Primeiro, por uma questão de delimitação do espaço do poder, retira da população o direito de "resolver sua carência de moradia" por conta própria. Para se contrapor ao "contrapoder", compra fazendas nos arredores da cidade, constrói conjuntos habitacionais de baixa qualidade, promove parcelamentos, tudo à revelia da legislação urbana vigente. Ao fazer isso, repassa a imagem de que é sua a responsabilidade pelos assentamentos humanos. A ação do Estado nesse período, diga-se, revestido de ilegalidade e de populismo, atende duplamente os interesses do capital imobiliário. Libera áreas "deterioradas" centrais e segrega na zona rural um grande contingente da população pobre, assentando-a longe do mercado de trabalho e rompendo com as relações de amizade, de vizinhança. Ao promover a ocupação desse espaço com assentamentos tipicamente urbanos, o Estado deteriora uma área de reserva ambiental e coloca em risco o abastecimento de água da cidade.

Esses "movimentos de urbanização" constituem um novo enquadramento teórico que ajuda a explicitar a dinâmica urbana que marca profundamente a formação do espaço de Goiânia e dos municípios sob sua área de influência até o inicio dos anos 1990.

Esta periodização está inconclusa e precisa ser atualizada, o que não será feito neste artigo. Vale lembrar, entretanto, que esta atualização está em curso, necessitando ser sistematizada a partir de um amplo projeto de pesquisa sobre o mercado imobiliário na metrópole goianiense. ${ }^{2} \mathrm{~A}$ ausência de um novo período que contemple o estado atual da arte sobre a questão imobiliária na Região Metropolitana de Goiânia e o seu papel na reconfiguração do espaço urbano, entretanto, não altera em nada a fragilidade política do planejamento praticado em Goiânia. Ressalte-se que este se mantém subserviente ao capital imobiliário, assim como perdura a debilidade dos governos para assegurar a construção de espaços urbanos que tragam reais benefícios à maioria da população.

\section{Raízes históricas do desordenamento urbano de Goiânia}

No final dos anos 60, Goiânia ainda era uma cidade muito jovem. Tinha menos de 40 anos e já se apresentava no cenário nacional como um polo de desenvolvimento regional.

Nas década de 60 e 70, sua população urbana registrou uma das maiores taxas de crescimento do país, ou seja, $9,5 \%$ para a população total e $10,5 \%$ para a população urbana ao ano, conforme mostra a Tabela 1

Esse dinamismo populacional dos anos 60 reflete uma tendência de crescimento que se iniciara nos anos 50, quando a taxa de crescimento já era elevada (10,31\%, conforme Tabela 2), o que colocava Goiânia como uma cidade de fronteira, portanto, um "novo Eldorado".

Nesse período, no dizer de MOYSÉS; PAIVA; CUEVAS, 1992:24. "Goiânia se consolidava como centro populacional, administrativo, comercial, financeiro e de serviços, perdendo o estilo predominante de cidade meramente administrativa". ${ }^{3}$ 
Também contribuiu para esse dinamismo a perda do controle de terras para efeito de parcelamento, pelo Estado, para os grandes proprietários de terras do entorno de Goiânia. Com isso, a cidade passou a expandir-se de forma desordenada, na medida em que novos loteamentos eram lançados numa velocidade muito grande. As unidades eram comercializadas, porém grande parte dos lotes não era edificada de imediato.

Tabela 1 - Taxa Média Geométrica de Crescimento Anual da População da Aglomeração de Goiânia 1960-70 e 1970-80

\begin{tabular}{l|c|c|c|c|c|c}
\hline \multirow{2}{*}{\multicolumn{1}{c|}{ Municípios }} & \multicolumn{2}{|c|}{ Taxa de crescimento anual 60-70 } & \multicolumn{2}{c}{ Taxa de crescimento anual 70-80 } \\
\cline { 2 - 7 } & Total (\%) & $\begin{array}{c}\text { Urbana } \\
(\%)\end{array}$ & Rural (\%) & Total (\%) & $\begin{array}{c}\text { Urbana } \\
(\%)\end{array}$ & Rural (\%) \\
\hline Aparecida de Goiânia & & & & 19,2 & 37,4 & 12,9 \\
\hline Goiânia & 9,5 & 10,5 & $-1,2$ & 6,8 & 7,1 & $-2,3$ \\
\hline Goianira & 1,9 & 8,3 & 0,5 & 2,2 & 12,3 & $-4,9$ \\
\hline Nerópolis & 1,6 & 3,6 & $-0,4$ & 2,0 & 5,4 & $-4,2$ \\
\hline Senador Canedo & & & & 1,3 & $-2,9$ & 3,6 \\
\hline Trindade & 2,8 & 7,0 & $-1,5$ & 3,3 & 5,1 & $-0,4$ \\
\hline Total da Aglomeração & $\mathbf{8 , 7}$ & $\mathbf{1 0 , 3}$ & $\mathbf{0 , 6}$ & $\mathbf{6 , 9}$ & $\mathbf{7 , 3}$ & $\mathbf{2 , 0}$ \\
\hline
\end{tabular}

Fonte: Elaborado pelo autor com base nos dados do IBGE - Censos Demográficos

Além da dinâmica populacional, as atividades econômicas, como consequência dessa dinâmica, também foram expressivas, na medida em que Goiânia tornou-se um centro regional de compras, constituindo um entreposto comercial para o Centro-Oeste e para a Amazônia, onde os produtos voltados para a agroindústria eram os que mais se destacavam.

Tabela 2 - Taxa Média Geométrica de Crescimento Anual da População da Aglomeração de Goiânia 1950-60

\begin{tabular}{l|c|c|c}
\hline \multirow{2}{*}{ Municípios } & \multicolumn{3}{c}{ Taxa crescimento anual 1950-60 (\%) } \\
\cline { 2 - 4 } & Total & Urbana & Rural \\
\hline Aparecida de Goiânia & & & \\
\hline Goiânia & 11,1 & 12,8 & 4,0 \\
\hline Goianira & 15,6 & 8,7 & 17,2 \\
\hline Nerópolis & 1,4 & 5,0 & $-0,8$ \\
\hline Senador Canedo & & & \\
\hline Trindade & $-0,1$ & $-1,6$ & 1,1 \\
\hline Total da Aglomeração & $\mathbf{9 , 1}$ & $\mathbf{1 1 , 2}$ & $\mathbf{3 , 9}$ \\
\hline
\end{tabular}

Fonte: Elaborado pelo autor com base nos dados do IBGE - Censos Demográficos

Vários fatores contribuíram para acelerar o crescimento populacional e dinamizar a sua economia. ${ }^{4}$ Dentre eles podemos destacar os seguintes: ainda que de modo incipiente, no setor industrial predominavam as empresas de pequeno e médio porte voltadas basicamente para o mercado local e estadual; a construção de Brasília, que exerceu grande influência no processo migratório para Goiânia; a construção civil que, além de produzir grande número de edificações, viu fortalecer as construtoras e incorporadoras locais, com destaque para a ENCOL S/A, que viria, anos depois, se tornar uma empresa nacional; a transferência de renda do setor rural para as atividades urbanas, beneficiando a cidade como um todo, porém com destaque para os setores da construção civil, com o lançamento de casas e prédios de alto padrão, e das concessionárias de veículos.

Mercator - volume 8, número 17, 2009: set./dez. 
Um outro aspecto que merece ser destacado são as alterações processadas no âmbito da legislação urbana e que interferiram na dinâmica da cidade. Até 1947, o parcelamento urbano era de responsabilidade do poder público, o qual arcava com todos os custos de infra-estrutura.

Por um lado, o controle do poder público sobre as terras urbanas no município de Goiânia era importante, na medida em que possibilitava um crescimento mais ordenado da cidade. Sua expansão dava-se de forma mais harmônica, não existindo vazios urbanos, sendo o desenho urbano definido na medida em que havia demanda por mais espaços construídos, obedecendo a um Plano de Urbanização para a cidade. Esse Plano, por sua vez, propunha a evolução da cidade através da aprovação de cidades- satélites que deveriam se desenvolver ao redor do núcleo original constituído pelos setores Central, Norte, Sul e Oeste. ${ }^{5}$

De outro, havia uma pressão muito grande por parte dos proprietários de terras que queriam se aproveitar do novo pique de demanda provocado pelos fatores já mencionados, ${ }^{6}$ percebendo a possibilidade de participação nesse promissor mercado imobiliário que se configurava em concorrência com a administração pública. As imobiliárias, incorporadoras e construtoras foram beneficiárias das mudanças que ocorreram no âmbito da legislação urbana em vigor.

Neste sentido, as pressões dos segmentos interessados surtiram efeito. O governo do Estado, em 1947, fez aprovar o Código de Edificações de Goiânia. ${ }^{7}$

Os empreendedores, entretanto, reagiram contra as exigências de que eles se responsabilizariam pela implantação da infra-estrutura nos novos loteamentos. As pressões desse grupo resultaram numa nova Lei Municipal, a de $\mathrm{n}^{\circ} 176$, de 16/3/50, que revogava essa exigência, facilitando, assim, as ações dos empreendedores no que se refere ao parcelamento urbano. A partir desse momento, o poder público perde a autonomia de legislar sobre o uso do solo urbano, bem como o controle da expansão da cidade.

Esse novo processo traria consequências sérias para a cidade, a médio e a longo prazo. A cidade, desde os anos 50, fica à mercê da iniciativa privada, que passa a desenhar a cidade de acordo com a lógica da economia de mercado. O que importa aos empreendedores (proprietários de terras, imobiliárias, incorporadoras e construtoras) é a maximização de seus ganhos. A terra urbana deixa de ser um bem social e transforma-se numa mercadoria, sendo o seu valor de troca fator determinante no ritmo das transações. Assim, o acesso à terra urbana só é possível através de compra ou aluguel.

Com isso, o crescimento de Goiânia, desde então, se dá de forma desordenada, caótica, fugindo das orientações formuladas pelo Plano Diretor em vigor. O poder público perde a gestão sobre a cidade. Como consequência, os espaços verdes exigidos pelo Plano Diretor conseguem resistir até meados dos anos 70. A partir daí, os vazios urbanos passam a substituir os espaços verdes, colocando a periferia, do ponto de vista geográfico, mais distante do centro urbanizado.

$\mathrm{O}$ avanço da periferia, aqui entendida enquanto espaços segregados e distantes da malha urbana, provocados pela lógica da acumulação de capital, gera dois efeitos com repercussões sobre o processo de adensamento.

Primeiro, eleva os custos da terra, tornando-a proibitiva à grande maioria da população, fazendo com que os pobres procurem resolver seus problemas de moradia em locais cada vez mais distantes; segundo, em decorrência do primeiro, transforma a população pobre em "agentes de destruição", ou seja, tendo que resolver seus problemas de moradia em locais cada vez mais distantes, acabam por colocar em risco áreas importantes do ponto de vista de sua preservação, ameaçando reservas ambientais necessárias ao equilíbrio ecológico.

Goiânia, apesar de sua posição periférica, não está fora do processo de acumulação de capital e, tampouco, indiferente ao contexto de globalização da economia. Assim, para a economia local a terra é um bem e, por isso, constitui-se numa reserva de valor que assume a função de mercadoria, podendo ser trocada livremente pelo seu valor de mercado. O estoque dessa mercadoria permite, portanto, ao seu proprietário, maximizar ganhos, sem que para isso tenha realizado qualquer tipo de investimento, graças à reserva de valor que ela encerra. 
Neste sentido, a especulação imobiliária é a grande beneficiária, na medida em que a existência de espaços vazios na malha urbana, à espera de valorização, contribui para a segregação da força de trabalho em locais distantes dos empregos, desprovidos de qualquer benefício público. A esse respeito, afirma KOWARICK, 1979, p. 80-81:

"De um lado, tem sido um dos principais fatores do crescimento caótico da cidade, pois cria "periferias" cada vez mais longínquas dos centros de emprego e, ao mesmo tempo, gera um padrão de sedimentação habitacional rarefeito e descontínuo, impedindo que uma imensa massa humana seja beneficiada com bens de consumo coletivo básicos. De outro, como a rapidez de valorização destes vazios está associada à implantação desses serviços, o poder público tem desempenhado um papel fundamental na diferenciação dos preços da terra, servindo, com os investimentos que realiza, ao processo de especulação imobiliária". Dessa forma, acrescenta, "como acumulação e especulação andam juntas, a localização da classe trabalhadora passou a seguir os fluxos dos interesses imobiliários" (idem, 31).

Como conseqüência, cabe destacar, dentre muitos, um aspecto que caracteriza os anos 50 e 60 e que vai marcar o processo de ocupação do solo urbano nas décadas seguintes. Nunca o setor imobiliário maximizara tanto os seus ganhos, diga-se de passagem, a custo "quase zero". ${ }^{8}$ Fazia dinheiro na ponta com a venda dos lotes mais distantes, praticamente sem custos, já que a responsabilidade dos loteadores era obedecer à localização indicada e fazer apenas o arruamento, enquanto as áreas reservadas valorizavam-se com os investimentos que o poder público fazia, também sem custo para a iniciativa privada, como é o caso da pavimentação das vias coletoras ${ }^{9}$ para o transporte coletivo que ligava o centro urbanizado até os novos loteamentos e a rede de energia elétrica.

No processo de ocupação do solo urbano de Goiânia destacam-se três atores que se mantêm presentes até hoje: o Estado, o capital imobiliário e a população que demanda espaço por moradias (MORAES,1991), seja ela organizada ou não. A história urbana de Goiânia está marcada por conflitos de interesses, e as alianças estabelecidas entre eles nem sempre consideram a idéia histórica de que a cidade é conhecida e reconhecida como uma cidade planejada. O fato é que o desenho urbano da cidade conforma e expressa os interesses em conflitos. De um lado, o capital imobiliário impõe seus projetos, desenha e redesenha espaços que até então pareciam consolidados, cria e recria novas centralidades; de outro, os movimentos de luta pela casa própria também se projetam sobre a cidade e deixam uma aparência de que também são atores que reordenam o espaço urbano. $\mathrm{Na}$ verdade, na correlação de forças, estes perdem mais do que ganham, não conseguem ter direito à cidade e acabam se localizando nas áreas menos urbanizadas que o capital, temporariamente, permite.

Existe um processo permanente de desestruturação do espaço urbano nas grandes cidades, com efeitos mais perversos nas áreas metropolitanas. Estes se expressam no parcelamento desordenado de áreas, glebas e fazendas ainda disponíveis dentro das cidades; na especulação imobiliária incontrolável; nos processos de favelização, com a proliferação de loteamentos clandestinos e áreas de posse, muitas vezes, ocupando áreas de preservação ambiental, fundos de vales e áreas de risco; na ausência de equipamentos urbanos, de infra-estrutura e de saneamento básico; na poluição do sistema hídrico e na degradação da paisagem natural e do meio ambiente; no aumento dos índices de violência urbana e na deterioração da qualidade de vida da população.

O avanço desordenado da cidade de Goiânia sobre as matas ciliares vem exigindo da Prefeitura de Goiânia desde os anos 1960, quando o potencial construtivo da cidade se revestiu de caráter capitalista mais explícito, a execução de políticas de proteção e recuperação dos fundos de vale, por meio de intervenções articuladas. Pelo fato de a Prefeitura de Goiânia não se antecipar às ações antrópicas e institucionais, o que se verifica atualmente é que o adensamento cerca a quase totalidade dos cursos d'água que cortam a cidade, conforme a figura 1. A figura 1 mostra apenas parte dos recursos hídricos da cidade. Percebe-se que a malha edificada praticamente ocupou todos os fundos de vale, apesar de ainda se notarem pequenas manchas verdes em alguns pontos dos cursos d'água.

Mercator - volume 8, número 17, 2009: set./dez. 


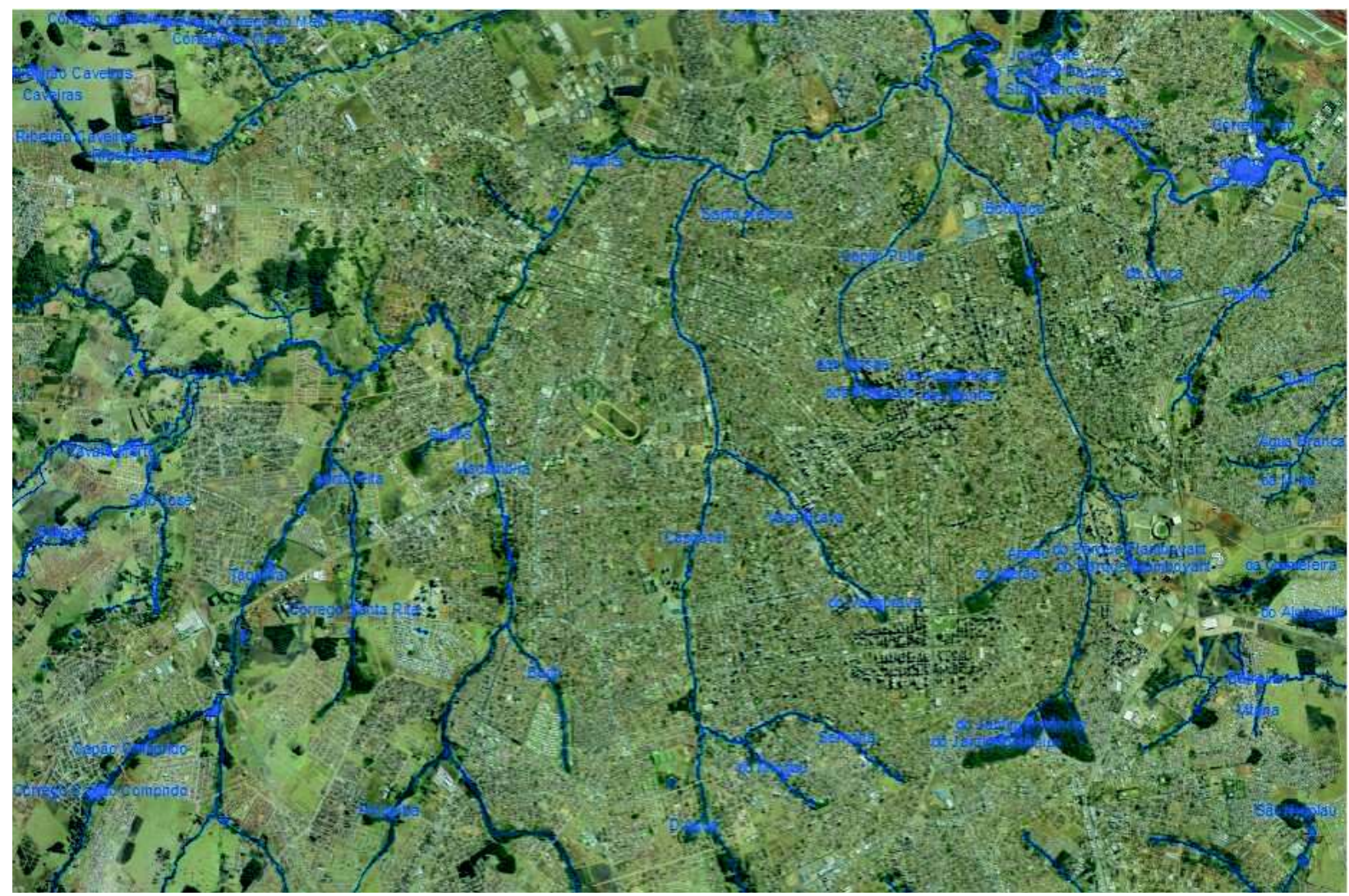

Figura 1 - Vista parcial dos principais cursos d'água de Goiânia

Fonte: Prefeitura de Goiânia - Secretaria Municipal de Planejamento - Ortofoto 2006

Em decorrência deste processo, os problemas ambientais no município de Goiânia, segundo estudos realizados pela Secretaria Municipal de Planejamento para a revisão do Plano Diretor de Goiânia, estão basicamente relacionados aos seguintes aspectos:

a) Ao desmatamento excessivo da cobertura vegetal original tanto na zona rural, pelos empreendimentos da agricultura e da pecuária, quanto na zona urbana, pelo parcelamento urbano;

b) A poluição dos corpos d'água, principalmente os que drenam a malha urbana, devido ao não tratamento dos esgotos industriais e domésticos;

c) A ocupação desordenada do Solo Urbano, com o agravamento de processos erosivos e de assoreamentos, com a proliferação de áreas de risco e freqüentes alagamentos de vias dentro da malha urbana;

d) As alterações climáticas, com a formação de ilhas de calor nas regiões mais densamente povoadas e impermeabilizadas;

e) A poluição atmosférica, devido a inversões térmicas ocasionadas por uma quantidade relativamente grande de poluentes na atmosfera, sobretudo do monóxido de carbono;

f) A poluição visual, pela quantidade excessiva de propaganda através de outdoors, principalmente no Centro Expandido e nas redondezas dos grandes equipamentos urbanos como Shoppings;

g) Ao intenso tráfego de veículos na malha urbana da cidade, com inúmeros pontos críticos de engarrafamento;

h) A degradação dos Parques e outras Unidades de Conservação. 
Não se pode atribuir exclusivamente ao crescimento populacional a ocupação desordenada dos espaços urbanos, sobretudo das áreas de preservação e fundo de vales. São vários os fatores que determinam o crescimento populacional muito acima das taxas de crescimento vegetativo, assim como também são conhecidas as razões que levam o setor imobiliário a pressionar para ocupar os espaços mais rentáveis. Por razões óbvias, esses fatores não serão discutidos neste artigo. Entretanto, cabe destacar que políticos e políticas equivocadas, aliadas ao capital imobiliário, sabem como se utilizar da pressão de demanda que os vários segmentos populacionais exercem sobre o poder público. Este, dada a sua fragilidade, não consegue se colocar acima dos interesses individuais e de grupos e acaba por ceder às pressões e, muitas vezes, assume o ônus das intervenções no urbano.

Mesmo assim, vamos considerar a evolução da população, observando o quadro abaixo.

Tabela 3 - Goiânia - População Total e Participação Relativa da População Urbana e Rural

\begin{tabular}{|c|c|c|c|c|c|}
\hline \multirow{2}{*}{ Censos } & \multirow{2}{*}{ Total } & \multirow{2}{*}{ Urbana (\%) } & \multirow{2}{*}{ Rural (\%) } & \multicolumn{2}{|c|}{$\begin{array}{l}\text { Taxa de Crescimento Anual - Pop } \\
\text { Urbana }\end{array}$} \\
\hline & & & & Período & $\%$ \\
\hline 1940 & 48.166 & 31,2 & 68,8 & & - \\
\hline 1950 & 53.389 & 74,7 & 25,3 & $1950-1940$ & 10,3 \\
\hline 1960 & 153.505 & 86,9 & 13,1 & $1960-1950$ & 12,8 \\
\hline 1970 & 381.055 & 95,3 & 4,7 & 1970-1960 & 10,5 \\
\hline 1980 & 738.117 & 98,1 & 1,9 & 1980-1970 & 7,1 \\
\hline 1991 & 922.222 & 99,1 & 0,9 & $1991-1980$ & 2,1 \\
\hline 2000 & 1.093 .007 & 99,3 & - & 2000-1991 & 1,9 \\
\hline
\end{tabular}

Fonte: IBGE - Censos Demográficos - Quadro Organizado pelos autores.

Ao analisar a Tabela 3, nota-se que a pressão migratória sobre a cidade de Goiânia tem sido crescente num longo período. Desde os anos 50 até os anos 80, ou seja, num período de 40 anos consecutivos, o crescimento da população urbana tem se dado a taxas muito elevadas. Nas décadas de 50 a 70 as taxas de crescimentos da população urbana foram superiores a $10 \%$ ao ano. A década de 80 apresentou taxas menores $(7,1 \%$ ao ano), o que se explica pelas altas taxas de crescimento dos municípios que compõem sua Região Metropolitana. Em termos absolutos, o incremento populacional de Goiânia é superior ao dos demais municípios, entretanto, cabe registrar que o pólo metropolitano continua sendo atraente, porém parte deste fluxo fica retida nos municípios do entorno, onde, em tese, as condições para se morar são mais acessíveis.

O setor imobiliário, constituído por proprietários de terras, construtoras e incorporadoras, atento a essa mobilidade, procura aumentar a velocidade de seus negócios, ora sendo alavancados pelos recursos públicos (SHERFAU, BNH, COHABS, CEF), ora utilizando recursos próprios, combinados com recursos adiantados pelos futuros consumidores. Neste sentido, a dinâmica urbana de Goiânia ganha força já na década de 60, com a implantação de infraestrutura nas ruas dos setores Bueno e Marista, quando se inicia o processo de verticalização da Capital, sinalizando para as grandes transformações urbanas que viriam nas décadas seguintes. A população urbana das décadas seguintes (1970 e 1980) já supera 95\% da população total, apresentando índices elevados de concentração no espaço urbano.

Em 10 anos (de 1975 a 1985), segundo dados da SEPLAM, foram construídas cerca de 60 mil novas unidades habitacionais, sendo mais de 17.000 apartamentos distribuídos em aproximadamente 4.300 novos condomínios verticais. Paralelamente a esse boom imobiliário voltado para a classe média, a cidade também se horizontaliza com a construção de conjuntos habitacionais, autoconstrução em lotes próprios e, com o processo acelerado de urbanização, aumenta também o crescimento das invasões de áreas públicas e, principalmente, privadas. 
Este processo extensivo de horizontalização da cidade gera dois efeitos: amplia a periferização da cidade e se aproxima dos municípios vizinhos, produzindo os primeiros espaços conurbados. ${ }^{10}$ Também decorrem do acelerado processo de urbanização dois fenômenos que vão repercutir sobre o meio ambiente: o avanço da ocupação das matas ciliares e várzeas junto aos cursos d'água e o aumento substancial da impermeabilização do solo, que são os principais causadores da situação de falta de controle no que se refere à preservação ambiental.

Parte dos fluxos migratórios que conseguiram ficar retidos em Goiânia vão buscar nos fundos de vale a solução para suas moradias, áreas estas que mais deveriam receber atenção no que se refere à preservação ambiental. Estas concentrações populacionais, na forma de favelas ou invasões, agravam mais ainda a situação de degradação dos cursos d'água, na medida em que o lixo e o entulho doméstico gerados por estas "habitações", além do esgoto sanitário, têm os cursos d'água como receptores naturais, causando problemas sanitários e dificultando o processo de drenagem.

A seguir será analisado como estas questões podem ser enfrentadas pelo poder público, quando este produz políticas públicas de intervenção urbanística com grande alcance sobre as populações mais fragilizadas.

\section{PROBLEMAS E SOLUÇÕES SOCIOAMBIENTAIS A SEREM ENFRENTADOS PELO PROGRAMA MACAMBIRA-ANICUNS}

As Figuras 2 e 3 mostram o córrego Cascavel desaguando no ribeirão Anicuns, que antes já recebera o córrego Macambira e, em seguida, o curso d'água do córrego Botafogo. Por isso, a bacia do ribeirão Anicuns é a principal do Município, drenando toda a área central de Goiânia e parte das regiões oeste, sul e leste, cobrindo cerca de $70 \%$ da população.

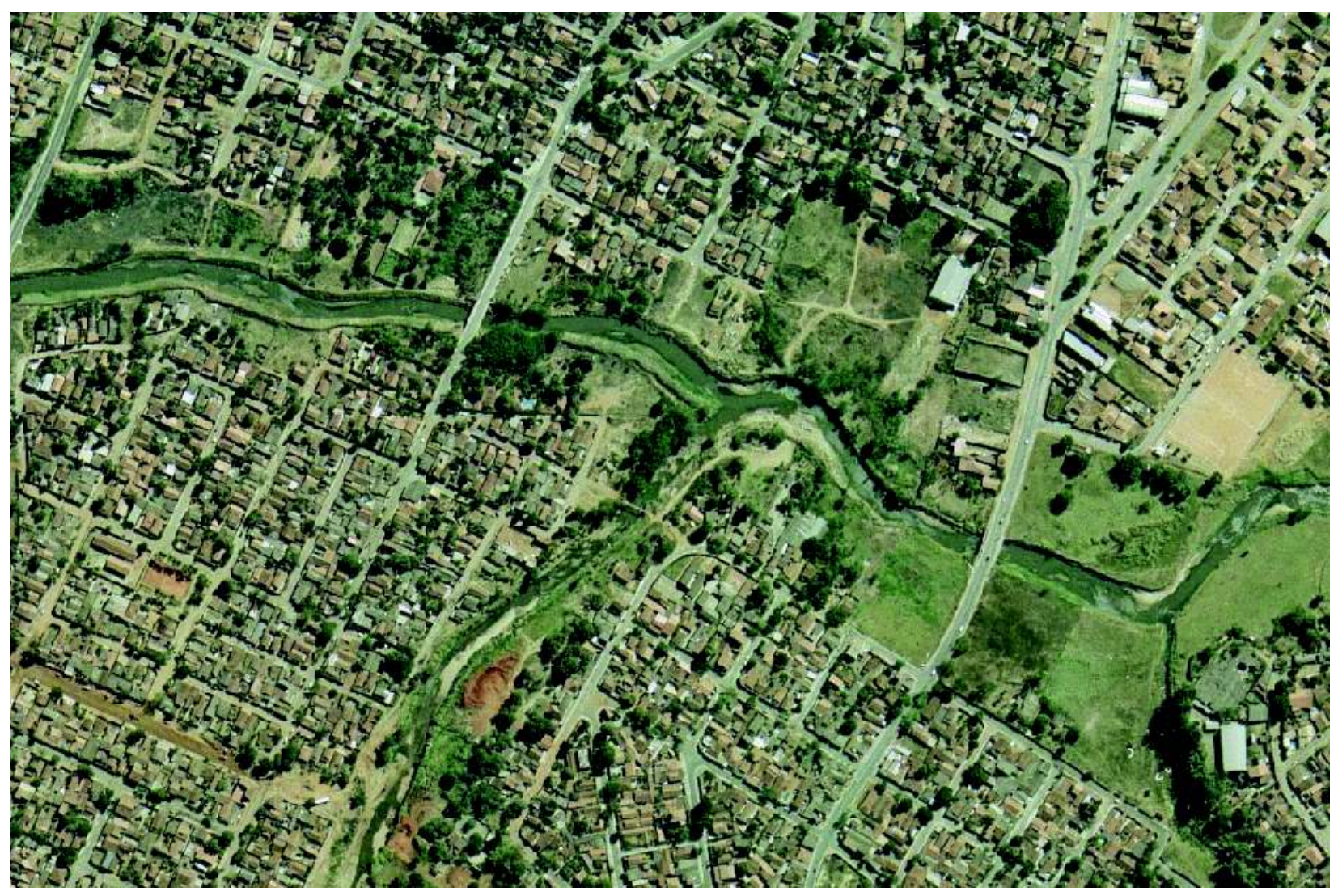

Figura 2 - Vista geral do ribeirão Anicuns, quando recebe o córrego Cascavel Fonte: Prefeitura de Goiânia - Secretaria Municipal de Planejamento - Ortofoto 2006 
O avanço da ocupação das margens destes cursos d'águas por residências, comércios e indústrias é intenso, inclusive em áreas de risco como planícies de inundação. Esta situação, somada às condições sanitárias dos cursos d'água, cria uma condição imprópria e de risco à saúde pública e à segurança. O processo de degradação dos vales do córrego Macambira e do ribeirão Anicuns tende a se intensificar, caso não sejam tomadas medidas para sua proteção e recuperação. A tendência é aumentar a ocupação clandestina dos fundos de vale, o que dificultará no futuro a sua reurbanização.

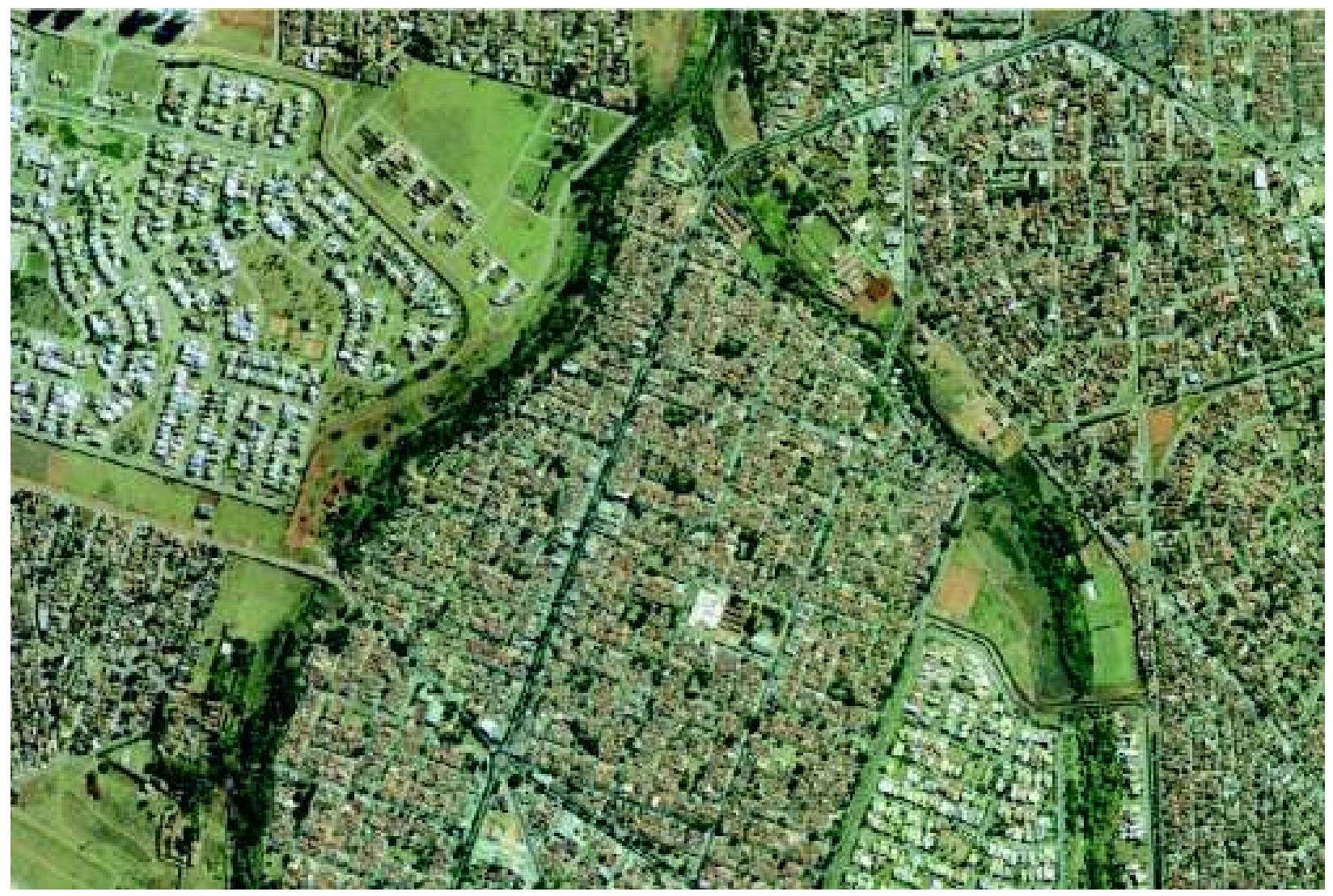

Figura 3 - Vista geral do córrego Macambira

Fonte: Prefeitura de Goiânia - Secretaria Municipal de Planejamento - Ortofoto 2006

Neste sentido, o programa Macambira-Anicuns tem como objetivo fortalecer o processo de desenvolvimento sustentável de Goiânia, solucionando os problemas socioambientais resultantes da ocupação desordenada das margens do córrego Macambira e do ribeirão Anicuns, e promovendo a efetiva participação dos cidadãos no processo de planejamento e gestão. O programa abrange ações nas áreas de meio ambiente, urbanização, habitação e sistema viário, em uma área superior a 5 (cinco) milhões de metros quadrados, ou seja, cerca de 500 ha nas regiões norte, noroeste e oeste de Goiânia.

Percebe-se, com o auxílio da Figura 4, que a vasta área do programa está urbanizada e acha-se envolta por uma região fortemente adensada. Segundo o documento Prefeitura de Goiânia, 2005:10, a quantidade de imóveis existentes no percurso do córrego Macambira e ribeirão Anicuns (margens de $30 \mathrm{~m}$ de cada lado), é da ordem de 780, sendo que, deste total, 52\% são terrenos desocupados que representam 405 imóveis; 41\% são moradias, num total de 322 imóveis, nos quais se estima uma população de 1.127 moradores aproximadamente; 2,7\%, ou seja, 24 imóveis, são edificações destinadas a atividades econômicas e 6,\% (29 imóveis) são de uso institucional. A totalidade destes imóveis forma uma superfície de mais de 4 milhões de $\mathrm{m} 2$.

Todas estas edificações serão removidas para a construção de um Parque Linear e de três Parques Ambientais Urbanos (Macambira, Pedreira do Morro, Parque das Águas), qualificando sensivelmente a vida dos moradores da região e oferecendo à população em geral novas opções 
de lazer e entretenimento. O programa prevê ações indenizatórias para o programa de remoções das famílias e dos que desenvolvem atividades produtivas na área objeto de intervenção, a maioria constituída de pequenos negócios.

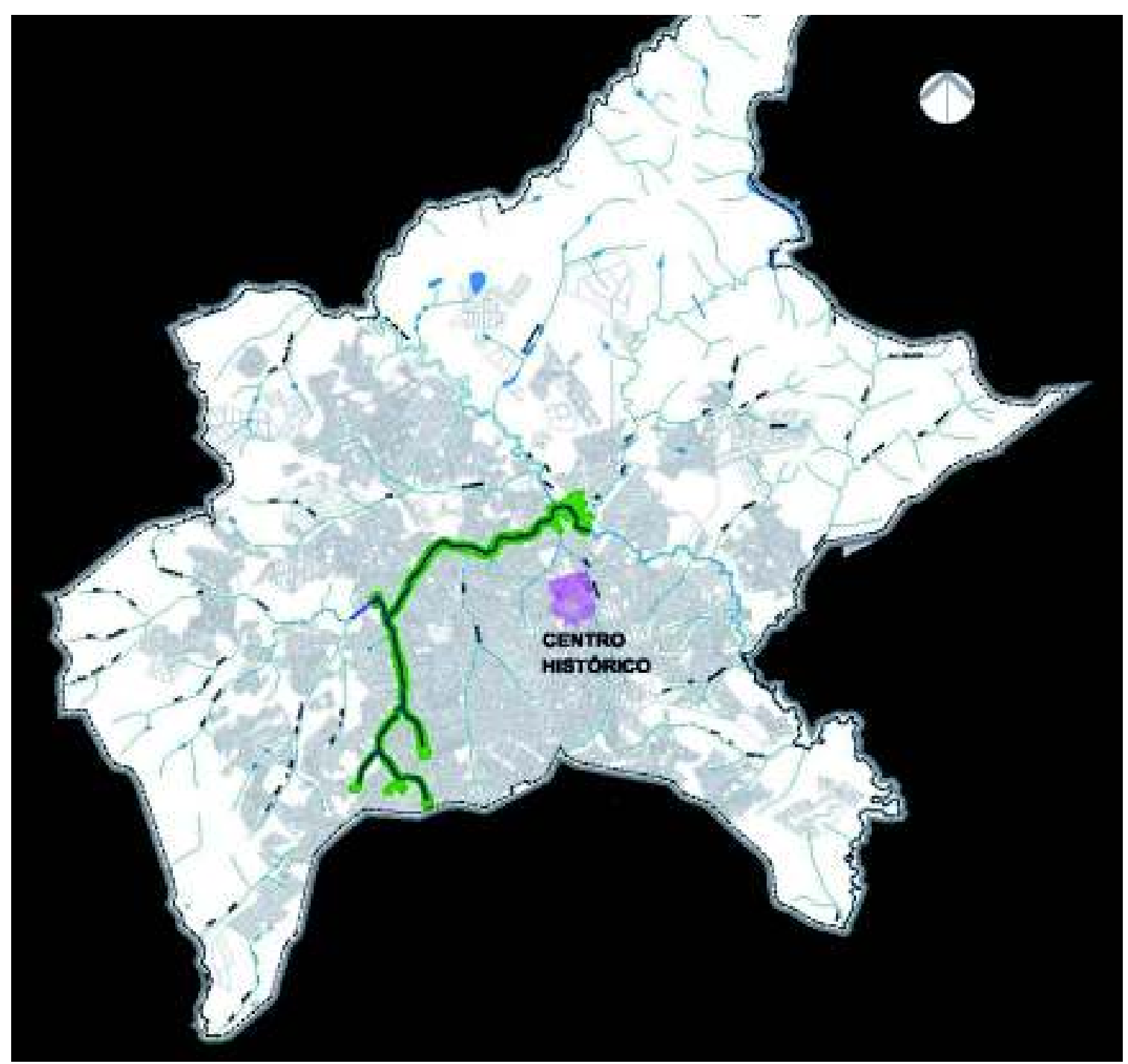

Figura 4 - Vista abrangente do Programa Macambira-Anicuns

Fonte: Prefeitura de Goiânia - Secretaria Municipal de Planejamento - Projeto Macambira-Anicuns

Em linhas gerais, o programa Macambira-Anicuns sustenta um discurso bastante progressista no que se refere às intervenções urbanas e no envolvimento da população na sua gestão. No que se refere às intervenções urbanísticas, três ações são de grande relevância;

a) Melhoria das condições ambientais do córrego Macambira e do ribeirão Anicuns, mediante a reabilitação e adequação do sistema de drenagem, a organização da ocupação do solo e a proteção ambiental das áreas vulneráveis.

b) Melhoria das condições de vida da população residente na zona de influência do projeto, mediante a implantação de infraestrutura urbana e social, de maneira a maximizar os benefícios socioeconômicos da organização urbano-ambiental.

c) Melhoria da capacidade operacional e de gestão das instituições municipais envolvidas no programa. 
Do ponto de vista ambiental, o projeto propõe a recuperação ambiental de áreas de preservação permanente dos fundos de vale do córrego Macambira, desde sua nascente, e do ribeirão Anicuns, entre a foz do Macambira e o Rio Meia Ponte, e a criação de Unidades de Conservação Ambiental na área de influência direta e indireta do projeto, totalizando mais de 3 milhões de metros quadrados de áreas a serem recuperadas e preservadas, ou seja, mais da metade da área de abrangência do programa.

Propõe, também, a incorporação e a recuperação de uma extensa área de fundo de vale, hoje degradada com a presença de esgotos domésticos e industriais, entulhos e resíduos sólidos de toda ordem. E, por fim, a adequação da proposta urbana às novas condições sanitárias do Rio Meia Ponte e do ribeirão Anicuns. A recuperação das áreas de preservação permanente será realizada com a revegetação dos fundos de vale, e sua proteção será feita através de ações que garantam não somente a recuperação das áreas de nascentes e faixas ciliares, mas também a sua preservação futura.

Consta nos documentos oficiais que o projeto prevê também a recuperação dos fundos de vale na sua área de influência, respeitando e protegendo planícies de inundação naturais e buscando controlar inundações em áreas habitadas.

No tocante à gestão do projeto, sobretudo no que se denomina de "gestão compartilhada do processo de desapropriação e remanejamento", momento crítico de qualquer intervenção urbana quanto à participação dos atores a serem atingidos pelas ações do programa, se prevê a adoção de mecanismos avançados de participação popular. Do documento, Prefeitura de Goiânia, 2005:38-39, extraem-se as seguintes proposições:

A Gestão Compartilhada do ciclo de implantação do PARR/Macambira Anicuns requer:

Criação de um sistema sócio organizacional, composto por duas instâncias: a) uma Comissão Geral de Representantes da Comunidade (CGR) composta por lideranças dos afetados residentes na faixa de 30 metros do Macambira e do Anicuns, e estes representantes deverão ser eleitos pelas famílias alvo de remanejamento em evento específico para tanto; b) Comissões de Apoio Local (CAL), formada por representantes das famílias alvo de remanejamento; c) Comissão Consultiva (COS) formada por representantes das famílias alvo de suas instituições públicas e privadas, sendo nove membros indicados pelo governo e os demais representantes de varias instâncias sociais e entidades privadas.

Definição das ações básicas que deverão ser realizadas para uma base operacional física plasmada em um Escritório de Gestão Local (ELO).

Uma base física para viabilizar aplicação do Modelo de Gestão Compartilhada, através da instalação de um Escritório de Gestão Local em cada uma das margens do Macambira e do Anicuns. Nestes escritórios estará, diariamente, durante toda a execução do PARR, uma equipe técnica habilitada a atender as famílias em suas dúvidas e inquietações sobre o processo de remanejamento. Estes escritórios constituem, também, base operacional indispensável para garantir a contento realização de ações capitais do processo de remanejamento, tais como aquelas afeitas à Atualizações do Cadastro Socioeconômico, Controle da Ocupação da Área Afetada e Adesão das Famílias por Alternativas de Remanejamento. Os dois Escritórios Locais de Gestão Compartilhada serão implantados e coordenados pela UGPI e contarão com uma equipe composta por 1 engenheiro com conhecimento dos projetos de obras a serem implantados; 5 assistentes sociais; 2 advogados; 1 especialista em comunicação social, os quais prestarão serviços para a população alvo de remanejamento, diariamente, em período integra (...). Os grifos são do documento.

No mesmo documento, afirma-se que haverá eleições diretas para todas as instâncias de participação, assim como gestão técnica permanente e comprometida com o espírito das ações a serem desenvolvidas, a fim de se assegurar um controle permanente antes, durante e depois do programa de intervenção. 


\section{ALCANCE DAS INTERVENÇÕES URBANAS}

O projeto é considerado de grande importância para a população residente nas margens dos córregos Macambira e do ribeirão Anicuns, assim como para a população da região, estimada em cerca de 300 mil pessoas, distribuídas em 104 bairros de Goiânia, que seriam beneficiárias deste Programa, ou seja, aproximadamente $1 / 4$ da população atual. O programa, como um todo, prevê a execução das seguintes obras:

- Construção de 4 pontes e reabilitação de outras 3 ao longo do ribeirão Anicuns;

- Ampliação de 5 bueiros ao longo do córrego Macambira;

- Atendimento de 90 bairros na área de abrangência do programa, com a implantação dos seguintes equipamentos: construção e informatização de Escolas de Tempo Integral, construção e/ou reabilitação e informatização de Centros Municipais de Educação Infantil, construção, reabilitação e equipamentos de Postos de Saúde, complementação do asfalto e drenagem pluvial, equipamentos sociais, tais como praças, áreas de lazer, quadras etc.;

- Parque linear, visando à reconstrução da paisagem ambiental e urbana dos fundos de vale situados entre a nascente do córrego Macambira e a foz do ribeirão Anicuns, com 26,5 Km de extensão por $60 \mathrm{~m}$ de largura mínima, totalizando 232 hectares, abrangendo $2.620 .000 \mathrm{~m} 2$, incluindo em toda a sua extensão: $26,5 \mathrm{~km}$ de ciclovias e passeios de pedestres com iluminação diferenciada; 46 espaços comunitários e 42 pontes de pedestre para travessia dos córregos; recuperação de 159 hectares com vegetação nativa; 3 Unidades de Conservação com 1.150 mil $\mathrm{m}^{2}$ e reassentamento e regularização fundiária da população atingida;

Do ponto de vista da sustentabilidade social e institucional, o programa também prevê as seguintes ações: fortalecimento da gestão ambiental urbana; educação ambiental e comunicação urbana e gestão da manutenção urbana.

No que se refere aos trâmites burocráticos, o projeto já concluiu as seguintes etapas:

- Formatação do projeto e aprovação no COFIEX,

- Projeto básico de engenharia, estudos ambientais, econômicos e de sustentabilidade,

- Missões de análise do BID,

- Minuta de contrato,

- Aprovação pelo Diretório do BID,

- Assinatura do contrato em 16 de setembro de 2009.

O aval ao Projeto vem da União (Secretaria do Tesouro Nacional), que respalda junto ao BID a capacidade de pagamento da Prefeitura Municipal de Goiânia que tem aporte financeiro para arcar com o ônus da contrapartida financeira do projeto.

O custo total é de 94,5 milhões de dólares, sendo 60\% financiado pelo BID - Banco Interamericamo de Desenvolvimento, e 40\% com recursos da Prefeitura Municipal de Goiânia, tendo como fiador, a Secretaria do Tesouro Nacional. O prazo para concluir a obra é de 5 (cinco) anos a partir da assinatura do contrato, e o início da mesma está previsto para março de 2010. Conforme o Programa Conexão Ambiental (setembro 2009),

O mais audacioso projeto socioambiental brasileiro, o Macambira-Anicuns, vigora oficialmente a partir de hoje, dia 16. O prefeito Iris Rezende e o representante do Banco Interamericano de Desenvolvimento (BID) no Brasil, José Luiz Lupo, assinaram a liberação de recursos que garantirão 
a reurbanização das regiões Sudoeste, Oeste e Norte de Goiânia (...). A previsão é de que obras comecem já no primeiro trimestre de 2010. O primeiro edital deve ser lançado dentro de 60 dias.

Na contrapartida da Prefeitura, alguns custos já foram realizados, tais como a contratação de consultorias para a elaboração dos estudos e projetos até o momento executados. Obras localizadas nas proximidades do projeto podem também ser computadas como recursos da Prefeitura alocados no programa. $\mathrm{O}$ prazo de amortização é de 25 anos e a carência é de 2 anos.

\section{CONSIDERAÇÕES FINAIS}

A implantação deste programa, num primeiro momento, sinaliza que haverá enormes ganhos para a população que mora nas proximidades deste empreendimento. As autoridades acreditam que o benefício também se estenderá para a cidade em geral, na medida em que esta intervenção do poder público, ao revitalizar as bacias do córrego Macambira e do ribeirão Anicuns, possibilitará o acesso da população a uma diversidade de ambientes destinados ao lazer e à contemplação. Em outros termos, haverá de fato a apropriação pelo poder público de uma extensa área, transformando-a em um bem público com reflexos diretos na qualidade de vida da população da cidade.

Este programa de intervenção urbana tem gerado discursos eivados de ufanismo, como se percebe no texto do Programa Conexão Ambiental (setembro 2009),

O Macambira-Anicuns deve guinar o turismo na Capital. Isso porque Goiânia terá o maior parque linear do mundo com 26,5 quilômetros de extensão, 46 espaços comunitários - entre quadras poliesportivas, praças, pista de cooper, laboratórios, orquidário, borboletário, aquário, lagos, auditório, teatros, centros culturais, ciclovia -, além de 42 pontes de pedestres para travessia dos córregos. Os equipamentos serão instalados ao longo da mata ciliar e ocuparão, no mínimo, 60 metros de largura e, no máximo, de 200 metros.

Também ocorrerá a reabilitação de 13 pontes, construção de escolas em tempo integral, Centros Municipais de Educação Infantil (Cmeis), postos de saúde e equipamentos sociais. Ao longo do leito dos dois cursos de água haverá ainda a reabilitação das calhas e a recomposição das margens.

A concepção do programa é inovadora se considerarmos a prática urbanística adotada pelos sucessivos governos locais, muitas vezes com forte ingerência do governo estadual. Nesta, o componente mais forte que o programa coloca é a recuperação dos cursos d'água, aliado a uma política de resgate social que se contrapõe àquela que, historicamente, sempre norteou o ordenamento da cidade pela ótica do transporte individual. Os cursos d'água de Goiânia sempre foram vistos como panacéia para resolver problemas do transporte individual. Acreditava-se que a única forma de garantir uma maior mobilidade por parte da população motorizada era ocupar os fundos de vale com vias destinadas ao veículo motorizado individual. ${ }^{11}$ Este projeto pode estar abortando este tipo de concepção urbana e, talvez por isso, tenha demorado tanto a decisão de sua implantação.

Trata-se de um programa de grande alcance social e ambiental, com reflexos positivos para o conjunto da cidade, inclusive do ponto de vista econômico. É importante registrar estas expectativas, até mesmo para se poder conferir, no futuro, a veracidade de seus propósitos.

A natureza deste programa de intervenção urbanística é, de fato, um marco importante no processo de construção da cidade de Goiânia. Do ponto de vista crítico, entretanto, cabe destacar dois aspectos importantes: um de natureza histórica e outro de natureza prospectiva.

Do ponto de vista histórico, o programa traz no seu bojo uma crítica ao processo histórico de urbanização da metrópole goianiense. Ao longo de seu processo de urbanização, não se desenvolveram instrumentos para assegurar a preservação dos corpos d'água que cortam a cidade de Goiânia e houve omissão no que se refere à preservação de seu espaço rural. Apesar de ser cantada e decantada pela qualidade de seus índices de arborização, os investimentos na recuperação e preservação ambiental não vão além da construção de parques, plantio de árvores e flores tropicais.

Mercator - volume 8, número 17, 2009: set./dez. 
Não há, atualmente, políticas consistentes de preservação dos mananciais que abastecem a cidade nem de recomposição de sua vegetação natural, sobretudo das matas ciliares.

Os espaços verdes de sua generosa zona rural - com aproximadamente $300 \mathrm{~km} 2$ de terra descontínua $^{12}$ - estão sob ameaça constante, tanto por parte dos Poderes Executivo e Legislativo quanto da iniciativa privada que pressiona esses dois poderes visando a incorporação de glebas rurais à malha urbana. Neste sentido, existem vereadores na Câmara Municipal que defendem abertamente a extinção do que ainda resta de zona rural e sua transformação em zona urbana. ${ }^{13}$

O Plano Diretor aprovado pela Câmara Municipal, paradoxalmente, possibilita alguns riscos para a cidade. Dentre as nove diretrizes para o seu ordenamento, duas telas podem trazer consequências sérias para o seu futuro: estabelecer a macroestruturação do território; propiciar tratamento equilibrado ao território, rompendo a dicotomia urbano/rural.

No espaço deste artigo, não é possível discutir mais profundamente essas diretrizes. Preliminarmente, entretanto, pode-se dizer que ambas as diretrizes vão criar condições objetivas para um processo intensivo de construção em toda a cidade, o que não deixa de ser danoso para os cofres públicos, na medida em que eliminam as linhas imaginárias de segmentação do espaço (urbano e rural) e possibilitam a liberação para edificações (vertical ou horizontal) em qualquer ponto da cidade. Consequentemente, ou melhor, contraditoriamente, isto geraria a ocupação desordenada da cidade, aumentaria os espaços vazios entre os aglomerados populacionais e oneraria o poder público, já que este assumiria a responsabilidade pela implantação dos serviços públicos.

Curiosamente, estas duas diretrizes podem comprometer outras duas previstas no Capítulo I do Plano Diretor de Goiânia: disciplinar e ordenar o uso do solo; reconhecer o meio ambiente como determinante físico às ocupações. Na verdade, estas diretrizes se constituem na espinha dorsal do Plano Diretor, pois são elas que podem assegurar o ordenamento da cidade de forma mais saudável. Deixemos essa discussão para outro artigo.

Do ponto de vista prospectivo é preciso ser realista, porque um programa desta natureza, mesmo considerando a força sinergética de suas ações, não poderá ser visto como única saída para o enfrentamento dos problemas relacionados ao ordenamento urbano, quer seja do ponto de vista físico ou sociocultural. Num país onde o Estado ainda é subjugado pelas forças econômicas e estas se acham sujeitas à dinâmica do mercado, ou seja, às dinâmicas do modo de produção capitalista, não se pode esperar que as intervenções públicas no espaço urbano se dêem sempre na perspectiva do que este programa sinaliza. Este fato inegável trás por si só dificuldades que nem sempre são solucionadas no âmbito da política local, já que as forças econômicas locais estão inseridas no processo de globalização da economia. Isto, entretanto, nem sempre ocorre com a política, já que ela é determinada muito mais pelas injunções dos atores locais e nem sempre se acha conectada às políticas nacionais. Neste sentido, devido aos objetivos do programa (revitalização de espaços degradados), já estão em curso algumas consequências de caráter social:

a) A população para a qual o projeto foi elaborado não será a mesma que se beneficiará das ações a serem implantadas, isto porque, a partir do momento em que o poder público sinaliza que o programa vai deslanchar, inicia-se também a especulação imobiliária.

b) Já são visíveis as modificações na paisagem urbana da região, onde a ocupação horizontal do espaço cede lugar ao processo de verticalização.

c) Contraditoriamente, o programa traz como consequência a elevação do custo da terra e, como desdobramento, a expulsão da população originária para locais mais distantes e desprovidos de infraestrutura social e física. Ou seja, os diversos territórios que compõem a área de abrangência do programa passam também por um processo de valorização da terra que força a população citadina a vender seus imóveis, edificados ou não, para segmentos sociais mais abastados. 
Enfim, nada disso é estranho, porque planejamento urbano nos marcos do capitalismo, por mais importante que possa ser, sempre será um instrumento de intervenção limitado e subjugado pelas forças hegemônicas da sociedade.

\section{NOTAS}

(1) Detalhes sobre esse processo estão em Moysés (1996: capítulos 2 e 3). Resumindo: um grupo de aproximadamente 100 (cem) pessoas inicia a ocupação de uma gleba de terra de aproximadamente 26 alqueires goianos (126 hectares) na região oeste da cidade, denominada de "Fazenda Caveirinha", sendo que tal ação acaba por atrair novos interessados. O Estado, para impedir os efeitos futuros dessa ação popular, chama para si e assume o processo de ocupação na região. Isso ocorre na fase final da ditadura militar. Tal processo continua depois da redemocratização do país, curiosamente deteriorando não só o espaço construído, mas também o "meio ambiente".

(2) No âmbito do INCT/OBSERVATÓRIO DA METRÓPOLES, está se desenvolvendo o projeto Impactos da dinâmica imobiliária construtiva (mercado formal e informal) na reconfiguração espacial da RM de Goiânia. Este projeto, de grande amplitude, pretende: elaborar mapeamento físico e social da produção do mercado formal e informal de moradias; estudar como a nova dinâmica imobiliária da RMG está se reproduzindo nos demais municípios metropolitanos; estudar os condomínios fechados urbanos e os condomínios de "chácaras" de alto padrão; avaliar os impactos das mudanças na estrutura de provisão de moradia e financiamento público (como o "Minha Casa Minha Vida") na organização social do espaço da metrópole goianiense; por fim, efetivar o cruzamento dos dados dos mercados formal e informal de Imóveis na RMG e a caracterização das respectivas tipologias habitacionais, com os dados da tipologia socioespacial do Observatório das Metrópoles.

(3) Esse texto foi produzido e incorporado ao Plano de Desenvolvimento Integrado de Goiânia-PDIG/1992.

(4) Mais detalhes a esse respeito, consultar Moraes (1991: 37-38).

(5) As cidades-satélites mencionadas no Plano Urbanístico Original de Goiânia, na prática não chegaram a ser instaladas. A ideia de cidades-satélites seria materializada quando da construção de Brasilia. A esse respeito, CAMPOS (1988:72) afirma: "Na concepção original de Brasília, as cidades-satélites viriam a existir quando a população do Plano Piloto atingisse os limites para os quais foi planejada de 500 a 700 mil habitantes, tornando, portanto, tal antecipação, um certo desvirtuamento do plano original”.

(6) Outros fatores podem ser citados como, por exemplo: "a política desenvolvimentista de Pedro Ludovico Teixeira (19511954) e do presidente Juscelino Kubitschek (1956-1961) para a região; o governo planejado de Mauro Borges (1961-1964); a consolidação de Goiânia como pólo da região Centro-Oeste; o desenvolvimento agropecuário do Estado principalmente ao Sul e Sudoeste; a instituição do processo de planejamento, primeiro a nível do município, com a elaboração dos planos para Goiânia (Luis Saia - 1959-1962) e posteriormente para o governo do Estado" MOYSÉS(1992:18) e PDIG (1992:11).

(7) O Código de 1947, criado pela Lei Municipal no 574, de 12 de maio de 1947, delimita as ações do poder público e repassa ao empreendedor a responsabilidade pela implantação de toda a infra-estrutura. Esse código reúne toda a legislação urbana da época sobre loteamentos, edificações, ocupação e uso do solo.

(8) Não foi possível levantar o volume de negócios imobiliários da época, mas é possível inferir que a atividade imobiliária e da promoção imobiliária movimentou grandes somas de investimentos. Os sinais estão na quantidade de apartamentos lançados nesse período.

(9) Muitas dessas vias, de qualidade precária, foram construídas sem galerias de águas pluviais, necessitando logo de manutenção.

(10) Vale esclarecer que a Lei $\mathrm{n}^{\circ} 4.526$, de 31/12/71, pela ótica do setor imobiliário, contribuiu para expandir a cidade de Goiânia para outros municípios, principalmente Aparecida de Goiânia, pelo fato desta Lei exigir dos loteadores a instalação de infraestrutura básica em loteamentos na capital.

(11) Exemplo desta prática é a canalização dos córregos Botafogo (área central) e Cascavel (sentido sul - oeste), cujas margens foram transformadas em vias marginais para a circulação exclusiva de veículos motorizados.

(12) Nova reorganização espacial que passa a vigorar a partir do Plano Diretor revisado e aprovado pela Câmara Municipal de Goiânia e publicado no D.O. do Município de Goiânia no 4.147, de 26 de junho de 2007. São substituídas as três macrozonas (urbana, expansão urbana e rural) por oito macrozonas: do Alto do Dourados, Alto do Anicuns I, Alto do Anicuns II, Capivara, Barreiro, João Leite, São Domingos, Lajeado e Macrozona Construída.

(13) Bruno Peixoto (PMDB) defende a urbanização absoluta da Macrozona Rural: "É uma idéia que desenvolvo, mas que ainda não foi transformada em projeto de lei. Pretendo que toda área do município seja urbana", citado no site http://www.dm.com. br/impresso/7785/p...xpansao_urbana. Outro vereador, Djalma Araújo (PT), não chega a tanto, mas caminha na mesma direção quando solicita ao governo municipal a incorporação de 4 alqueires da zona rural para a zona urbana: "Não é expansão urbana sem rumo e sem sentido. Trata-se de uma 'ilha' rural em meio a região urbanizada e com infra-estrutura. Não faz sentido permanecer assim”. citado no site http://www.dm.com.br/impresso/7785/p...xpansao_urbana 


\section{REFERÊNCIA BIBLIOGRÁFICA}

BERNARDES, Genilda Darc. Goiânia, Cidade Planejada/Cidade Vivida: Discurso e Cultura da Modernidade. Brasília: Departamento de Sociologia da Universidade de Brasília. Tese de Doutorado, 1998.

CAMPOS, Neio. A Produção da Segregação Residencial em Cidade Planejada. Departamento de Urbanismo/ Universidade de Brasília: (Dissertação de Mestrado), 1988.

CORDEIRO, Narcisa Abreu e QUEIROZ, Normalice Maria de. Goiânia - Embasamentos do Plano Urbanístico Original. Goiânia:IPLAN/IAB, 1990.

CORRÊA LIMA, Atílio. Goiânia - A Nova Capital de Goiás. In: IBGE - Goiânia. Rio de Janeiro. IBGE, Coletânea/Batismo Cultural de Goiânia, 1942.

DIÁRIO DA MANHÃ, Jornal. Macambira-Anicuns sai do Papel. Goiânia, Jornal Diário da Manhã, Cadernos Cidades, página 2, 10/07/09

DIÁRIO DA MANHÃ, Jornal. Macambira-Anicuns sai do Papel. Goiânia, Jornal Diário da Manhã, Cadernos Cidades, 30/10/09

GODOY, Armando Augusto de. Relatório Sobre a Conveniência da Mudança da Capital. In: IBGE - Goiânia: Rio de Janeiro: IBGE, Coletânea/Batismo Cultural de Goiânia, 1942.

LERNER, Jaime. Sistema Integrado de Transporte de Goiânia - Implantação do Transporte de massa. Etapa Preliminar. SEPLAN/INDUR/Escritório de Planejamento/PMG/Jaime Lerner - Planejamento Urbano Ltda, 1975.

KOWARICK, Lúcio. A Espoliação Urbana. Rio de Janeiro: Paz \& Terra, 1979.

MORAES, Lucia Maria. A Segregação Planejada: Goiânia, Brasília e Palmas. 01. ed. Goiânia: Editora da UCG, v. 01, 2003. 270 p.

MORAES, Sérgio. O Empreendedor Imobiliário e o Estado: O Processo de Expansão de Goiânia em Direção Sul (1975-1985). Brasília: Universidade de Brasília. (Dissertação de Mestrado), 1991.

MOYSÉS, A. PAIVA, K., CUEVAS, M. J (orgs). Antecedentes Históricos do Município de Goiânia. Goiânia: IPLAN. (Mimeo), 1992.

MOYSÉS, Aristides. Contradições de uma Cidade Planejada no Planalto Central Brasileiro: Segregação Sócio-Territorial em Goiânia. São Paulo: PUC/SP. Tese de Doutorado, 2001

MOYSÉS, Aristides. Goiânia, metrópole não planejada. Goiânia: Editora da UCG, 2004.

MOYSÉS, Aristides. Estado e Urbanização: Conflitos Sociais na Região Noroeste de Goiânia (Década de 1980). Programa de Ciências Sociais/PUC-SP. Dissertação de Mestrado, 1996.

PDIG/2000. Plano de Desenvolvimento Integrado de Goiânia. Goiânia: IPLAN, 1992.

PROGRAMACONEXÃO AMBIENTAL - site: http://programaconexaoambiental.wordpress.com/2009/09/16/ projeto-macambira-anicuns-sai-do-papel/\#comment-17 - 2009 setembro 16

SAIA, Luis. Plano Diretor de Goiânia, Vol. I e II, 1960/1964.

WILHEIM, Jorge. Plano de Desenvolvimento Integrado de Goiânia. Goiânia, PMG, 1969.

\section{Documentos}

DBO Engenharia Ltda. Reurbanização dos Vales do Macambira e Anicuns: estudo de impacto ambiental - EIA / DBO Engenharia Ltda. - Goiânia, 2004.

DBO Engenharia Ltda. RELATÓRIO DE IMPACTO AMBIENTAL - RIMA. Goiânia, 2004

Documentos do BID. Memorandos, 2005.

Prefeitura de Goiânia - Projeto Macambira-Anicuns. 2004

Prefeitura de Goiânia. PARR - Plano de Ações para Reposição de Moradias, Remanejamento de População e Reinstalação de Atividades Econômicas, 2005.

Trabalho enviado em outubro de 2009 Trabalho aceito em dezembro de 2009 